\author{
Anna Dymek, Anna Pecio \\ Zakład Anatomii Porównawczej \\ Instytut Zoologii i Badań Biomedycznych \\ Wydziat Biologii \\ Uniwersytet Jagiellonski \\ Gronostajowa 9, 30-387 Kraków \\ E-mail: anna.tyrkalska@doctoral.uj.edu.pl
}

\title{
POINSEMINACYJNE LOSY PLEMNIKÓW. RÓŻNE ASPEKTY MAGAZYNOWANIA PLEMNIKÓW U SAMIC W WARUNKACH NATURALNYCH I SZTUCZNYCH
}

\section{WSTEP}

Wśród obecnie żyjących kręgowców dominujaca strategia rozrodu jest wytwarzanie ogromnej liczby gamet składanych do środowiska zewnętrznego (= wody), w którym dochodzi do ich fuzji. Strategia ta jest typowa dla grup zasiedlajacych wodne środowisko, czyli ryb doskonałokostnych (Teleostei), stanowiących ponad 31 tysięcy gatunków obecnej fauny kręgowców (www.fishbase.org) oraz wśród płazów bezogonowych (Anura), których jest ponad 6760 (www.amphibiaweb. org). Płodność wielu gatunków nie przekłada się na ich wysoki sukces rozrodczy, a produkcja gamet, szczególnie jaj, jest niezwykle kosztowna, ze względu na zaopatrzenie przyszłego zarodka w materiał energetyczny zabezpieczajacy pierwsze jego etapy rozwoju. Większość gamet uwalnianych przez obie płcie do środowiska zewnętrznego często nie ma nawet szansy na zetknięcie się, a tym samym na zapłodnienie, ze względu na różne czynniki, jak np.: dystans pomiędzy gametami spowodowany ruchami wody, obecność drapieżników zwabionych składanymi oocytami zaopatrzonymi w żółtko, czy krótki okres żywotności plemników w środowisku odmiennym od warunków, jakie zapewniał układ rozrodczy samców. Plemniki są narażone m.in. na szok osmotyczny (hipoosmolarność w wodach słodkich, hiperosmolarność w wodach słonych) i zmianę pH środowiska.
Wprowadzenie plemników do układu rozrodczego samic w znaczny sposób zmieniło biologię rozrodu zwierząt. ElOFSSON i współaut. (2006) wykazali, że czas przeżywania plemników u ciernika Gasterosteus aculeatus (Gasterosteidae), gatunku $z$ zapłodnieniem zewnętrznym, znacznie wydłuża się w obecności płynu jajnikowego. Także LAHNSTEINER i PATZNER (2007), przetrzymując plemniki Alcichthys alcicornis $z$ rodziny głowaczowatych (Cottidae) w płynie jajnikowym, wykazali ich żywotność wydłużoną aż do 14 dni, podczas gdy w warunkach naturalnych ich żywotność trwa zaledwie kilka minut. Zjawiska te sugeruja, że sekrecje substancji wytwarzanych przez żeński układ rozrodczy skutecznie przyczyniaja się do wydłużenia żywotności plemników i zachowania przez nie zdolności do zapłodnienia. Potwierdzaja to dane przytoczone poniżej, dotyczace wszystkich grup kręgowców, stwierdzające składanie zapłodnionych jaj przez samice po kilku miesiacach, a nawet latach od ostatniego kontaktu $z$ samcami. Obserwacje te moga nasuwać przypuszczenie, że inseminacja i przetrzymywanie plemników zdolnych do zapłodnienia sa jedyna szansa rozrodu w wielu siedliskach o parametrach fizykochemicznych i biologicznych znacznie odmiennych od tych, które istnieja wewnątrz organizmu. Szczególnie (chociaż nie zawsze - patrz poniżej) dotyczy to gatunków tych grup taksonomicznych, które dostosowały się do życia w środowisku lądowym. Obecnie takie strate- 
gie obserwuje się wśród płazów ogoniastych (Urodela), które odbywaja zaloty na ladzie, jak np. salamandry bezpłucne (Plethodontidae), wśród lądowych gatunków płazów beznogich (Apoda) oraz u wszystkich owodniowców.

Sposób przekazywania plemników do dróg rodnych samic jest niezwykle zróżnicowany, podobnie jak struktury, które umożliwiaja ich przeżycie i zachowanie zdolności do zapłodnienia. Inseminacja i przetrzymywanie zdolnych do zapłodnienia plemników w ciele samicy umożliwia także czasowe i przestrzenne rozdzielenie procesu kojarzenia się par od procesu składania jaj. Jest to bardzo korzystne $\mathrm{w}$ środowiskach o dużej zmienności warunków sezonowych, np. kiedy łaczenie się $\mathrm{w}$ pary jest niezwykle łatwe $\mathrm{w}$ okresie suchym przy niskim poziomie wody, a składanie jaj w okresie deszczowym przy wysokim poziomie wody oraz obfitości pokarmu i kryjówek dla potomstwa (PUSEY i STEWART 1989, BuRNS i współaut. 1997). Inseminacja, a następnie przechowywanie plemników zdolnych do zapłodnienia przez dłuższy czas, jest korzystna również $\mathrm{w}$ sytuacji, kiedy miejsce i czas, w których następuje kojarzenie się $\mathrm{w}$ pary są rozbieżne $\mathrm{z}$ tymi, które sprzyjaja składaniu jaj chociażby ze względu na dostępność pokarmu dla narybku. U Cymatogaster agregata samica przetrzymuje plemniki zachowujace zdolność do zapłodnienia przez co najmniej 6 miesięcy, gdyż owulowane oocyty pojawiaja się znacznie później w sezonie rozrodczym niż dojrzałe plemniki i jedynie taka strategia umożliwia sukces rozrodczy (GARDINER 1978). Podobne zjawisko zaobserwowano także u gatunków $\mathrm{z}$ rodzin Aphyonidae i Bythidae (Ophidiiformes), u których znajdywano spermatofory $\mathrm{w}$ jajnikach juwenilnych samic (NIELSEN 1984).

W przypadku poligamii przechowywanie plemników od różnych samców wiąze się $z$ konkurencja plemników (ang. sperm competition) pochodzących od różnych osobników i bardzo często $\mathrm{w}$ potomstwie jednej samicy występuje ojcostwo wielu samców (PARKER 1970). Wsród ryb doskonałokostnych takie zjawisko wystepuje u przedstawicieli piękniczkowatych Poeciliidae (CONSTANTZ 1984), Embiotocidae (DARLING i współaut. 1980), u skorpen Scorpaena (MUNEHARA i współaut. 1990), a wśród płazów ogoniastych u traszek (RAFIŃSKI i OSIKOWSKI 2002).

\section{JAK INSEMINACJA ZMIENIŁA BIOLOGIE ROZRODU?}

Pojawienie się $\mathrm{w}$ ewolucji inseminacji najczęściej skutkowało zapłodnieniem oocytów w organizmie samicy (w jajniku u ryb doskonałokostnych lub w jajowodach u pozostałych kręgowców) i umożliwiło składanie zygot (ang. zygoparity) lub ich przetrzymywanie, a następnie składanie jaj zawierajacych zarodki w różnych stadiach embriogenezy (ang. embrioparity) (PECIO 2001, 2012). W następnych etapach, dzięki modyfikacjom w układzie rozrodczym samic, mogła pojawić się tendencja do przetrzymywania zapłodnionych jaj, aż do momentu opuszczania przez nie osłonek jajowych, po czym zaraz następował poród (żyworodność fakultatywna). Kolejne modyfikacje w układzie rozrodczym samic doprowadzity do przetrzymywania zarodków w jajnikach (żyworodność obligatoryjna). Podczas dalszego rozwoju czerpały one substancje odżywcze $z$ nagromadzonego w oocytach żółtka (żyworodność lecytotroficzna) lub korzystały $z$ substancji odżywczych wytwarzanych przez organizm samicy (żyworodność matrotroficzna), co umożliwiało dalszy rozwój zarodków po wyczerpaniu się zapasów żóltka (HOAR 1969, AMOROSO 1960, HOGART 1976, WOURMS 1981, PECIO 2003). Tak więc inseminacja przyczyniła się do zmniejszenia liczby wytwarzanych gamet bez obniżania sukcesu rozrodczego, wpisując się $\mathrm{w}$ poczatkowe etapy ewolucji strategii rozrodczych ujawniających szerokie spektrum od „r” do „K” (teoria liczebności potomstwa).

\section{ADAPTACJE DO INSEMINACJI W RÓŻNYCH GRUPACH KREGOWCOWW}

Inseminacja ewoluowała niezależnie i wielokrotnie wśród różnych grup kręgowców. $\mathrm{Na}$ przykład wśród ryb doskonałokostnych pojawiła się aż w 27 spośród 420 rodzin (JAVONILlO i współaut. 2009, PECIO 2010). Pojawianie się inseminacji $\mathrm{w}$ grupach niespokrewnionych ze soba doprowadziło do powstania różnorodnych adaptacji behawioralnych, morfologicznych i fizjologicznych u obu płci, a także modyfikacji ultrastruktury gamet (GRIER 1981, MEISNER 2005, BURNS i WeITZMAN 2005, JAVONILLO i współaut. 2009). Przekazanie plemników poprzedzone jest skomplikowanymi zachowaniami godowymi, umożliwiającymi bezpośredni kontakt samca i samicy, co często wiąże się z powstawaniem trzeciorzędowych, wyraźnie zmienionych cech płciowych, np. barw.

Przekazanie plemników może odbywać sie poprzez kontakt samca i samicy w akcie kopulacji (np. ryby chrzęstnoszkieletowe, płazy beznogie, gady łuskonośne, ssaki łożyskowe), podczas krótkotrwałego kontaktu tzw. narządów wprowadzających kierujących strumień nasienia w kierunku gonoporu samicy ( $\mathrm{np}$. u ryb doskonałokostnych sa to gonopodium, priapium, andropodium, pseudopenis) lub podczas zetknięcia się kloak (np. 
większość ptaków) (PECIO 2010). Wyjątkiem $\mathrm{w}$ procesie inseminacji sa płazy ogoniaste, $\mathrm{u}$ których inseminacja dokonuje się całkowicie bez kontaktu między samcem i samica, podczas przekazania spermatoforu (PECIO i RAFIŃSKI 1985).

\section{STRUKTURY SŁUŻACE PRZECHOWYWANIU PLEMNIKÓW}

Pojawienie się inseminacji skutkowało powstaniem modyfikacji w strukturze gonad, co umożliwiło wydłużenie czasu przechowywania zdolnych do zapłodnienia plemników w żeńskim układzie rozrodczym (patrz poniżej). W zależności od grupy kręgowców, modyfikacje moga być zwiąane $z$ różnymi odcinkami układu (jajnik, jajowód lub kloaka).

Ryby chrzęstnoszkieletowe (Chondrichthyes) przechowuja plemniki w gruczole skorupowym, natomiast ryby doskonałokostne w jajniku. Gruczol skorupowy jest modyfikacją dystalnej części jajnika. Oprócz pełnienia swojej głównej funkcji, która jest produkcja na wczesnych etapach embriogenezy komponentów osłonki jajowej zapłodnionego jaja, jest też miejscem magazynowania plemników. Zjawisko to występuje zarówno w świetle, jak i w kanalikach gruczołu (np. PRATT 1993).

Ryby doskonałokostne moga przechowywać plemniki m. in. w kryptach jajnika, jak ma to miejsce np. u Helicolenus dactylopterus dactylopterus (VILA i współaut. 2007); plemniki moga też być zwiąane $z$ komórkami SAC (ang. specific epithelial cells) wyścielajacymi jajnik, co opisano u zmienniaka plamistego Xiphophorus maculatus (POTTER i KRAMER 2000). Dzięki pracom donoszacym o wewnętrznej asocjacji gamet u Scorpenidae

A

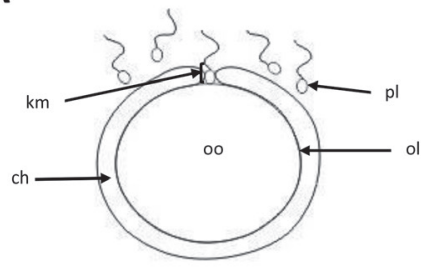

B
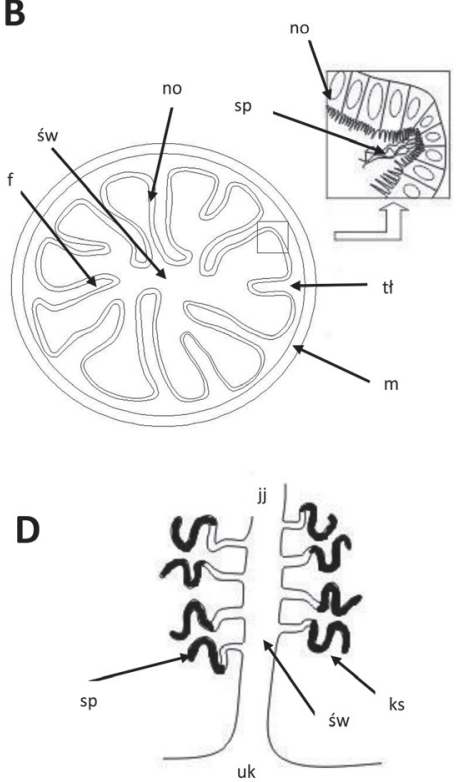

C

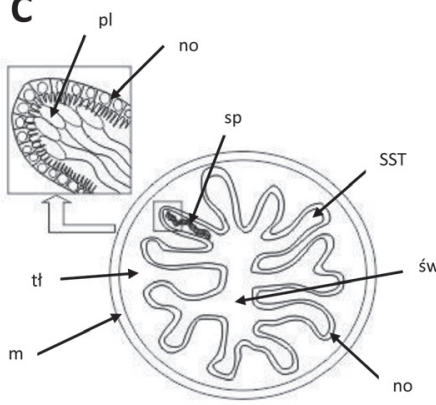

E

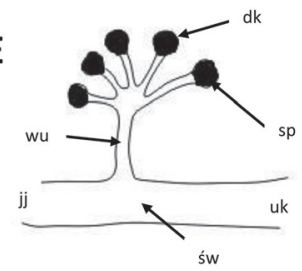

Ryc. 1. Schematyczne przedstawienie struktur służących magazynowaniu plemników.

A - mikropyle oocytu; B - krypty między fałdami błony śluzowej jajowodu płaza beznogiego I. cf. kohtaoensis; C kanaliki SST w jajowodzie A. truei; D - spermateka prosta; E - spermateka złożona. A, B, C - przekrój poprzeczny; D, E - przekrój podłużny. Objaśnienia: ch - kosmówka (chorion); dk - dystalna, pęcherzykowato zakończona część kanalika spermateki złożonej; f - fałd błony śluzowej jajowodu; jj - ujście jajowodów i jelita; ks - kanalik spermateki prostej; m - warstwa mięśniowa; no - nabłonek orzęsiony; ol - oolemma; oo - oocyt; pl - plemnik; sp - skupisko plemników; SST - kanalik SST; św - światło przewodu; tł - tkanka łączna; uk - ujście kloaki; wu - wspólne ujście kanalików spermateki złożonej. Schematy wykonano na podstawie zdjęć mikroskopowych zamieszczonych w cytowanej literaturze oraz własnych obserwacji. Aby zachować czytelność schematów, nie zachowano proporcji w wielkości pomiędzy poszczególnymi strukturami. 
(LAHNSTEINER i PATZNER 2007) oraz Cottidae (KoYA i współaut. 2002), za miejsce służące przechowywaniu plemników można uznać także mikropyle (ryc. 1A). Jest to miejsce na biegunie animalnym oocytu, przez które wnika plemnik. Jak wspomniano powyżej, płyn jajnikowy znacznie wydłuża żywotność znajdujących się w nim plemników. Dlatego tė̇ mikropyle, w którym zapewnione sa jednocześnie odpowiednie warunki dla utrzymania plemników oraz maksymalna bliskość gamet, wydaje się być idealnym rozwiąaniem zapewniajacym skuteczne zapłodnienie.

Płazy magazynuja plemniki w strukturach obecnych w jajowodzie (płazy bezogonowe i beznogie) lub będących uchyłkami w ścianach kloaki (płazy ogoniaste). Jedynym, jak dotąd, gatunkiem płaza beznogiego, u którego opisano magazynowanie plemników, jest Ichthyophis cf. kohtaoensis (KUEHNEL i KUPFER 2012). Samice tego gatunku magazynuja plemniki w kryptach między fałdami błony śluzowej dystalnej części jajowodu (Ryc. 1B), tzw. części macicznej.

Wśród płazów bezogonowych opis magazynowania plemników dotyczy obecnie również tylko jednego gatunku, Ascaphus truei (METTER 1964). Jest on wyjątkowy w swoim rzędzie, gdyż w przeciwieństwie do pozostałych płazów bezogonowych, u samców A. truei występuje narzad kopulacyjny, co wiąże się $z$ inseminacja i zapłodnieniem wewnętrznym (NOBLE 1925). Jest to adaptacja do środowiska życia (górskie, zimne strumienie o wartkim nurcie), które uniemożliwia zapłodnienie zewnętrzne. Samice tego gatunku przechowuja plemniki w tzw. kanalikach SST (ang. sperm storage tubules) (Ryc. 1C). Znajduja się one $\mathrm{w}$ jajowodzie i sa położone dystalnie w stosunku do miejsca, w którym jaja sa zaopatrywane w galaretowata otoczkę umożliwiajacca zapłodnienie (SEVER i współaut. 2001).

Większość gatunków płazów ogoniastych charakteryzuje obecność spermateki, czyli uchyłków w ścianie kloaki samic, służących magazynowaniu plemników (wyjątkiem sa trzy rodziny: Sirenidae, Hynobiidae, Cryptobranchidae, u których występuje zapłodnienie zewnętrzne). Wyróżniamy spermatekę prosta, złożoną $z$ licznych niezależnie uchodzących do kloaki kanalików (Ryc. 1D), oraz spermatekę złożona, w której pęcherzykowato zakończone kanaliki w dachu kloaki posiadaja jedno wspólne ujście (Ryc. 1E). Spermateka złożona charakteryzuje salamandry bezpłucne (Plethodontidae), natomiast spermateka prosta występuje w pozostałych rodzinach płazów ogoniastych (Ambystomatidae, Dicamptodontidae, Salamandridae, Rhyacotrytonidae, Proteidae, Amphiumidae) (SEVER i współaut. 2001).
Gady i ptaki, podobnie jak A. truei, magazynuja plemniki w kanalikach SST. U gadów znajdują się one w tylnej części lejka jajowodu (węże i większość jaszczurek), w pochwie (niektóre gatunki jaszczurek) i w gruczołach produkujących proteiny (u żółwi). U ptaków SST znajduja się w miejscu połączenia macicy i pochwy, a liczba kanalików może wynosić od 500 do 20.000 (BIRKHEAD i MøLLER 1992).

U ssaków miejscem przechowywania plemników do czasu zapłodnienia jest pochwa, szyjka macicy, jajowód [u krów, owiec i świń jest to cieśń jajowodu (łac. isthmus tubae uterine) (HUNTER 1984)]. Torbacze i niektóre owadożerne przechowuja plemniki w pecherzykowatych kieszonkach lub w kryptach utworzonych przez błonę śluzowa jajowodu (np. BEDFORD i współaut. 1999), natomiast u zdecydowanej większości ssaków plemniki sa związane $z$ nabłonkiem wyściełającym jajowód (np. SuAREz 1987).

\section{CZAS MAGAZYNOWANIA PLEMNIKÓW U SAMIC KREGGOWCÓW}

Wyraźna zmienność w długości czasu przechowywania plemników występująca między zwierzętami poikilotermicznymi (zmiennocieplnymi) a homojotermicznymi (stałocieplnymi, endotermicznymi) sugeruje, że u zwierząt zmiennocieplnych czas ten jest znacznie dłuższy.

\section{RYBY (PISCES)}

Wśród ryb chrzęstnoszkieletowych i doskonałokostnych, okres, w jakim odnajdywano żywotne plemniki w organizmach samic, zawierał się w przedziale od kilku dni, poprzez miesiące, aż do kilku lat (Tabela 1).

U samic rekinów należacych do gatunków Alopias vulpinus i Lamna nasus owulacja następuje już po kilku dniach od kopulacji. Plemniki sa przechowywane w świetle oraz kanalikach i kieszonkach gruczołu skorupowego, znajdującego się poniżej lejka jajowodu, co umożliwia natychmiastowe zapłodnienie jaj. Niedługo po zapłodnieniu, pozostałe plemniki zostaja usunięte $z$ organizmu samicy. Dzieje się to za pomoca tysięcy uwalnianych oocytów, które stanowia pożywienie dla rozwijajacych się młodych (PRATT 1993).

Bardzo rzadka strategię rozrodcza można zaobserwować u Alcichthys alcicornis z rodziny głowaczowatych (Cottidae). Została ona określona jako „wewnętrzna asocjacja gamet" (ang. internal gametic association). Po inseminacji i wniknięciu do jajnika plemniki wędrują do kanału mikropylarnego oocytu i tam sa przechowywane (nawet do 90 dni) do momentu składania jaj. Jednak dopie- 
Tabela 1. Zestawienie danych dotyczące magazynowania plemników u ryb.

\begin{tabular}{|c|c|c|}
\hline Takson & Czas trwania magazynowania plemników & Autor \\
\hline \multicolumn{3}{|c|}{ rekiny (żarłacze Squaliformes, rekinokształtne Galeiformes i koleniokształtne Squaliformes) } \\
\hline Alopias vulpinus & Kilka dni & PRATT 1993 \\
\hline Lamna nasus & Kilka dni & PRATT 1993 \\
\hline Scyliorhinus canicula & Kilka tygodni do kilku miesięcy & METTER 1941 \\
\hline Prionace glaca & Kilka tygodni do kilku miesięcy & PRATT 1993 \\
\hline Rhizoprionodon terraenovae & Kilka tygodni do kilku miesięcy & PRATT 1993 \\
\hline Carcharhinus obscurus & 10-15 miesięcy & PRATT 1993 \\
\hline Prionace glaca & 10-15 miesięcy & PRATT 1993 \\
\hline Sphyrna lewini, & 10-15 miesięcy & PRATT 1993 \\
\hline Mustelus antarcticus & 12 miesięcy & STORRIE i współaut. 2008 \\
\hline \multicolumn{3}{|c|}{ gupiki Poeciliidae } \\
\hline Xiphophorus maculatus & Kilka miesięcy & POTTER I KRAMER 2000 \\
\hline \multicolumn{3}{|c|}{ Sebastidae } \\
\hline \multicolumn{3}{|l|}{ terus } \\
\hline \multicolumn{3}{|c|}{ Cottidae } \\
\hline Alcichthys alcicornis & 90 dni & KOYA i współaut. 2002 \\
\hline \multicolumn{3}{|c|}{ Embiotocidae } \\
\hline \multirow[t]{2}{*}{ Micrometrus minimus } & 25 tygodni & DARLING $\quad$ i $\quad$ współaut. \\
\hline & & SchUltz 2008 \\
\hline Cymatogaster agregata & co najmniej 6 miesięcy & GARDINER 1978 \\
\hline
\end{tabular}

ro na zewnattrz organizmu, kontakt $z$ woda skutkuje fuzja gamet. Mimo że samica składa ikrę wielokrotnie w kilku-, kilkunastodniowych odstepach, podczas jednego tarła wszystkie jaja sa zapładniane przez zgromadzone w jajniku plemniki (KoYA i współaut. 2002).

Interesujaca jest także strategia rozrodcza obserwowana u żyworodnego Micrometrus minimus $z$ rodziny szumieniowatych (Embiotocidae). Nowonarodzone samce zapładniaja niedojrzałe płciowo samice. Plemniki sa przechowywane w jajnikach do 25 tygodni, do czasu osiagnnięcia przez samice dojrzałości płciowej (DARLING i współaut. 1980, Schultz 2008). Podobne zjawisko występuje u należacego do tej samej rodziny gatunku Cymatogaster agregata, gdzie plemniki sa przechowywane przez samice co najmniej 6 miesięcy (GARDINER 1978).

\section{PŁAZY}

W kolejnej gromadzie zwierzat zmiennocieplnych, czyli u płazów, spośród trzech rzędów (płazy ogoniaste, bezogonowe i beznogie) najwięcej danych na temat magazynowania plemników dotyczy płazów ogoniastych (Tabela 2), gdyż u większości gatunków dochodzi do zapłodnienia wewnętrznego, a samice posiadaja omówiona wcześniej, specjalna strukture do magazynowania plemników - spermatekę. W pozostałych dwóch rzędach znane sa tylko pojedyncze gatunki, u których opisano magazynowanie plemników (Tabela 2). Powodem takiego stanu rzeczy jest dominacja zapłodnienia zewnętrznego u płazów bezogonowych oraz słabe poznanie płazów beznogich, które sa jednak obecnie najintensywniej badana grupą płazów.

U płazów beznogich występuje zapłodnienie wewnętrzne, a samce posiadaja narząd kopulacyjny, tzw. fallodeum. KUEHNEL i KUPFER (2012) określili czas przechowywania plemników u Ichthyophis cf. kohtaoensis na minimum kilka tygodni. Mimo że obecnie brak doniesień dotyczacych magazynowania plemników u innych gatunków płazów beznogich, sugeruje się, że zjawisko to może występować u nich powszechnie.

Jak wspomniano wcześniej, jedynym gatunkiem płaza bezogonowego, u którego odnotowano magazynowanie plemników jest Ascaphus truei. METTER (1964) określił czas przechowywania przez samice zdolnych do zapłodnienia plemników na ok. 2 lata.

U płazów ogoniastych czas ten wynosi maksymalnie 6 miesięcy i zostało to odnotowane u Necturus beyeri i Notophthalmus viridiscens. Natomiast u Ambystoma tigrinum jest najkrótszy spośród obecnie opisanych gatunków i może wynosić mniej niż miesiąc (SEVER 2002). 
Tabela 2. Zestawienie danych dotyczące magazynowania plemników u płazów.

\begin{tabular}{llc}
\hline Takson & Czas trwania magazynowania plemników & Autor \\
\hline Ichthyophis cf. kohtaoensis & plazy beznogie Gymnophiona & \\
\hline \multicolumn{1}{c}{ min. kilka tygodni } & KUEHNEL i KUPFER 2012 \\
\hline Ascaphus truei & \multicolumn{1}{c}{ płazy bezogonowe Anura } & \\
\hline & ok. 2 lata & METTER 1964 \\
\hline Necturus beyeri & 6 miesięcy & SEVER 2002 \\
Notophthalmus viridiscens & 6 miesięcy & SEVER 2002 \\
Triturus vulgaris & $4-5$ miesięcy & SEVER 2002 \\
Rhyacotriton variegatus & $4-5$ miesięcy & SEVER 2002 \\
Plethodon cinereus & $4-5$ miesięcy & SEVER 2002 \\
Amphiuma tridactylum & $4-5$ miesięcy & SEVER 2002 \\
Eurycea cirrigera & $2-3$ miesiące & SEVER 2002 \\
Ambystoma opacum & $1-2$ miesiace & SEVER 2002 \\
\hline
\end{tabular}

\section{GADY}

U wszystkich gadów występuje inseminacja i zapłodnienie wewnętrzne, a samice cechuje obecność w jajowodzie opisanych wcześniej kanalików SST. Odnotowano u nich najdłuższy spośród wszystkich kręgowców czas magazynowania plemników, który może trwać nawet kilka lat, co zaobserwowano u wielu gatunków żółwi i węży (Tabela 3). Autorzy przytoczonych prac określali czas przechowywania plemników na podstawie obserwacji izolowanych od samców samic, które składały jaja po bardzo długim okresie od ostatniego kontaktu $Z$ samcami, lub na podstawie mikroskopowych

Tabela 3. Zestawienie danych dotyczace magazynowania plemników u gadów.

\begin{tabular}{|c|c|c|}
\hline Takson & Czas trwania magazynowania plemników & Autor \\
\hline \multicolumn{3}{|c|}{ żółwie } \\
\hline Terrapene carolina & 49 miesięcy (4 lata); & EWING 1943 \\
\hline & 14 miesięcy & HATTAN i GIST 1975 \\
\hline Malaclemmys terrapin & 49 miesięcy (4 lata) & BARNEY 1922 \\
\hline Chrysemys picta & 3 lata & PEARSE i współaut. 2001 \\
\hline Gopherus agassizii & 2 lata & PALMER i współaut. 1998 \\
\hline Chelonia mydas & 4 miesiące & ULRICH i PARKES 1978 \\
\hline Sternotherus odoratus & 3 miesiace & RISLEY 1933 \\
\hline Gopherus polyphemus & 3 miesiace & PALMER i GuILletTe 1988 \\
\hline \multicolumn{3}{|c|}{ jaszczurki } \\
\hline Anolis sagrei & powyżej 2 miesięcy & CALSBEEK i współaut. 2007 \\
\hline A. carolinensis & do 7 miesięcy & np. LiCHT 1973 \\
\hline Uta stansburiana & 3 miesiące & CUELlaR 1966 \\
\hline Moloch horridus & 2 miesiące & PHILIPP 1979 \\
\hline Acanthodactylus scutellatus & 4 miesiace & BOU-RESLI i współaut. 1981 \\
\hline Microsauria pumila & 6 miesięcy & ATSATT 1953 \\
\hline Chameleo hoelmelii & 9 miesięcy & JUN-YI 1982 \\
\hline Chameleo ellioti & 18 miesięcy & LEPTEIN 1989 \\
\hline Holbrookia propinqua & 3 miesiące & ADAMS i COOPER 1988 \\
\hline Eumeces egregius & 1 miesiąc & SCHAEFER i ROEDING 1973 \\
\hline Hemiergris peronii & 2 miesiące & SMYTH i SMITH 1968 \\
\hline
\end{tabular}




\begin{tabular}{|c|c|c|}
\hline Conolophus subcristatus & 12 miesięcy & WERNER 1982 \\
\hline \multicolumn{3}{|c|}{ hatterie } \\
\hline Sphenodon punctatus & 6 miesięcy & GABE i SAINT GIRONS 1965 \\
\hline Sphenodon guntheri & 1-2 miesiące & np. MoORE i współaut. 2008 \\
\hline \multicolumn{3}{|c|}{ krokodyle i aligatory } \\
\hline Paleosuchus palpebrosus & 16 miesięcy & DAVENPORT 1995 \\
\hline \multicolumn{3}{|l|}{ (1) } \\
\hline Acrochordas javanicus & 7 lat & MANGUSSON 1979 \\
\hline Leptodeira pohsticta & 6 lat & HAINES 1940 \\
\hline Agkistrodon blomhoji & 4,5 lat & FUKADA 1986 \\
\hline Thamnophis couchi hammondi & 4,5 lat & STEWART 1972 \\
\hline Drymarchon corais couperi & 4,5 lat & CARSON 1945 \\
\hline Xenodon merremii & 3 lata & DAREVSKY 1971 \\
\hline Agkistrodon contortrix mokasen & 2 lata & SCHUETT 1992 \\
\hline Thamnophis sirtalis & 3 miesiące & np. RAHN 1940 \\
\hline Storeria dekayi & 4 miesiące & TRAPIDO 1940 \\
\hline Causus rhombeatus & 5 miesięcy & WOODWARD 1933 \\
\hline Natrix subminiata & 5 miesięcy & KOPSTEIN 1938 \\
\hline Natrix vittata & 18 miesięcy & KOPSTEIN 1938 \\
\hline Natrix natrix & 6 miesięcy & np. ROLLINAT 1946 \\
\hline Leptodeira albofusca & 12 miesięcy & KLUTH 1936 \\
\hline Crotalus viridis & 5 miesięcy & np. LUDWIG i RAHN 1943 \\
\hline Vipera berus & 12 miesięcy & STILlE i współaut. 1986 \\
\hline Vipera aspis & 6 miesięcy & ROLLINAT 1946 \\
\hline Trimeresurus popeorum & 10 miesięcy & NICKERSON 1974 \\
\hline Trimeresurus albolabris & 13 miesięcy & HENLEY 1975 \\
\hline Boiga multimaculata & 12 miesięcy & KOPSTEIN 1938 \\
\hline Boiga dendrophila & 15 miesięcy & GROVES 1973 \\
\hline Coronella austriaca & 5 miesięcy & ROLLINAT 1946 \\
\hline Tropidoclonion lineatum & 5 miesięcy & np. GLOYD 1928 \\
\hline Agkistrodon contortrix & 13 miesięcy & ALLEN 1955 \\
\hline
\end{tabular}

obserwacji obecności plemników w układzie rozrodczym badanych samic, dlatego też dane te należy uznać za rzetelne.

\section{PTAKI}

Kręgowce stałocieplne wykazuja znacznie krótszy niż kręgowce zmiennocieplne czas przechowywania plemników, który u ptaków wynosi od kilku do kilkudziesięciu dni (Tabela 4). Najkrótszy czas zaobserwowano u myszołowa rdzawosternego Buteo jamaicensis, natomiast najdłuższy u indyka zwyczajnego Meleagris gallopauo - aż 117 dni (CHRISTENSEN i BAGLEY 1989). Jednak dane dotyczące indyka uzyskano wykonujac sztuczne zapłodnienie w warunkach laboratoryjnych. Celem badań było określenie optymalnej ilości nasienia używanej do inseminacji w hodowli indyków, co należy uwzględnić analizując dane zawarte w Tabeli 4.

\section{SSAKI}

Ssaki (z wyjątkiem nietoperzy) magazynują plemniki niezwykle krótko. Trwa to od kilku godzin do kilku dni (Tabela 5). Jedynie u nietoperzy, ze względu na hibernację, czas ten może wynosić nawet blisko 200 dni, gdyż kojarzenia par odbywaja się jesienia (a czasami także zima, w okresie hibernacji), natomiast wiosna jest czasem, kiedy dochodzi do owulacji i następującego po niej zapłodnienia. Dzięki temu, że owulacja jest odpowiedzia na zmiany warunków otaczającego środowiska, w danej populacji nietoperzy dochodzi do synchronizacji porodów wszystkich samic, gdyż sa one w takiej samej fazie cyklu reprodukcyjnego (RACEY 1982).

Można więc wysnuć wniosek, że im struktury służące do magazynowania plemników sa bardziej wyspecjalizowane, tym dłuższy jest czas przechowywania. Przy braku takich struktur, plemniki zmagaja się $z$ obcym środowiskiem układu rozrodczego samicy, co nie sprzyja utrzymywaniu ich żywotności przez dłuższy czas. Przedłużony czas magazynowania występuje u zwierząt, wśród których obserwuje 
Tabela 4. Zestawienie danych dotyczące magazynowania plemników u ptaków.

\begin{tabular}{lll}
\hline Takson & Czas trwania magazynowania plemników & Autor \\
\hline Meleagris gallopauo & $117 \mathrm{dni}$ & CHRISTENSEN i BAGLEY 1989 \\
Serinus canaria & $68 \mathrm{dni}$ & BIRKHEAD 1987 \\
Phianus colchicus & $42 \mathrm{dni}$ & SCHICK 1947 \\
Gallus domesticus & $35 \mathrm{dni}$ & NALBANDOV i CARD 1943 \\
Tetrao urogallus & $25 \mathrm{dni}$ & PARKER 1989 \\
Tragopan temminckii & $25 \mathrm{dni}$ & SPILLER i współaut. 1977 \\
Numida meleagris & $24 \mathrm{dni}$ & PETITJEAN 1966 \\
Nymphicus hollandicus & $24 \mathrm{dni}$ & BIRKHEAD 1988 \\
Anas platyrhynchos & $16 \mathrm{dni}$ & ELDER i WELLER 1954 \\
Falco sparverius & $15 \mathrm{dni}$ & BIRD i BUCKLAND 1976 \\
Diomedea melanophris & $14 \mathrm{dni}$ & ASTHEIMER i współaut. 1985 \\
Anser anser & $14 \mathrm{dni}$ & JOHNSON 1954 \\
Cairina moschata & $13 \mathrm{dni}$ & np. THIBAULT i LEVASSEUR 1973 \\
Aquila chrysaetas & $9 \mathrm{dni}$ & GRIER 1973 \\
Falco mexicanus & $8 \mathrm{dni}$ & BOYD i współaut. 1977 \\
Columba livia & $8 \mathrm{dni}$ & OWEN 1941 \\
Buteo jamaicensis & $6 \mathrm{dni}$ & GEE 1983 \\
\hline
\end{tabular}

się długi odstęp czasowy między inseminacja samicy a owulacja. W takim przypadku zapłodnienie możliwe jest tylko dzięki przechowywanym przez samice plemnikom (SAINT-GiRONS 1982). Dłuższy czas przechowywania plemników można także zaobserwować, gdy osiaganie dojrzałości płciowej samic i samców nie zachodzi w tym samym czasie (np. jeśli następuje to $\mathrm{w}$ różnych porach roku) (np. GuILleTTE i Sullivan 1985). Magazynowanie plemników przez długi czas jest także zabezpieczeniem przed brakiem partnera do rozrodu (PHILIPP 1979, JUN-YI 1982), np. $z$ powodu małego zageszczenia osobników na danym terenie (węże tropikalne) (SAINT-GIRONS 1982). Ponadto, magazynowanie może ograniczać do minimum ilość kopulacji w środowisku, gdzie istnieje zagrożenie częstymi atakami drapieżników. Przechowywanie plemników jest także preferowane, gdy owulacja trwa bardzo krótko i jest małe prawdopodobieństwo, że do kopulacji dojdzie w czasie owulowania jaj (BIRKHEAD i MøLLER 1993). Wśród nietoperzy czynnikiem wpływajacym na długi czas przechowywania plemników jest hibernacja tych zwierząt. Korzyścia samic nietoperzy wynikajaca $z$ tego zjawiska jest możliwość synchronizacji porodów (wszystkie młode danej samicy rodza się $\mathrm{w}$ jednym czasie) (RACEY 1982). Krótki czas magazynowania plemników można zaobserwować u zwierzat, wśród których nie ma długiego odstępu między kopulacja a owulacja, oraz gdy dojrzałość płciowa u samic i samców przypada $\mathrm{w}$ tym samym czasie.

\section{KRIOPREZERWACJA NASIENIA}

Definicja inseminacji oznacza unasiennienie, czyli wprowadzenie nasienia do dróg rodnych samicy (RożNIATOWSKI 1981). Ponieważ odnosi się to zarówno do inseminacji naturalnej, będącej skutkiem bezpośredniego przekazania nasienia lub via spermatofor, jak i sztucznej, następującej przez bezpośrednie wstrzyknięcie do dróg rodnych samicy nasienia pobranego od samca, omawianie zjawiska przechowywania plemników musi uwzględniać także przechowywanie plemników w warunkach laboratoryjnych. Krioprezerwacja nasienia jest ważnym aspektem hodowli i ochrony zagrożonych gatunków.

Aby inseminacje prowadzone $\mathrm{w}$ warunkach laboratoryjnych skutkowały zapłodnieniem zwierzat, należy brać pod uwage czynniki wpływające na jakość kriokonserwowanego nasienia. KOPEIKA i KOPEIKA (2008) podzielili je na dwie kategorie: czynniki zwiazane $\mathrm{z}$ (i) początkowa jakościa plemników oraz $z$ (ii) przeprowadzanymi procedurami laboratoryjnymi. Do pierwszej grupy należa m.in.: genom zwierzat, warunki ich rozwoju (dostępność pokarmu, temperatura, stopień natlenienia wody) czy też stopień dojrzałości samca w chwili pobierania nasienia. Natomiast do drugiej grupy można zaliczyć warunki, w jakich pobierano materiał, przechowywano plemniki oraz tempo rozmrażania nasienia.

Oprócz trudności związanych $\mathrm{z}$ jakościa kriokonserwowanego nasienia, napotyka się także inne, związane $\mathrm{m}$. in. $\mathrm{z}$ koniecznościa 
Tabela 5. Zestawienie danych dotyczace magazynowania plemników u ssaków.

\begin{tabular}{|c|c|c|}
\hline Takson & Czas trwania magazynowania plemników & Autor \\
\hline \multicolumn{3}{|c|}{ nietoperze } \\
\hline Nyctalus noctula & 198 dni & RACEY 1982 \\
\hline Pipistrellus abramus & $175 \mathrm{dni}$ & HIRAIWA i UCHIDA1956 \\
\hline Eptesicus fuscus & $156 \mathrm{dni}$ & WIMSATT 1944 \\
\hline \multicolumn{3}{|c|}{ torbacze } \\
\hline Didelphis virginiana & 0,5 dnia & RODGER i BEDFORD 1982 \\
\hline Macropus eugenii & 1 dzień & TyNDALE-Biscoe i ROdGer 1978 \\
\hline Sminthopsis macroura & 2,5 dnia & GODFREY 1969 \\
\hline Dasyurus viverrinus & $14 \mathrm{dni}$ & Hill i Donoghue 1913 \\
\hline Antechinus stuarti & $16 \mathrm{dni}$ & SELWOOD 1987 \\
\hline \multicolumn{3}{|c|}{ zajęczaki } \\
\hline Oryctolagus cuniculus & 1,3 dnia & HAMMOND i ASDELL 1926 \\
\hline Lepus europaeus & 30 dni & STAVY i TERKEL 1992 \\
\hline \multicolumn{3}{|c|}{ gryzonie } \\
\hline Mus musculus & $0,5-23 \mathrm{dni}$ & np. ULLMAN 1976 \\
\hline Cavia porcellus & 0,9 dnia & SODERWALl i YOUNG 1940 \\
\hline Rattus norvegicus & 0,6 dnia & SODERWALL i BLANDAU 1941 \\
\hline \multicolumn{3}{|c|}{ drapieżniki } \\
\hline Mustela putorius furo & $5 \mathrm{dni}$ & CHANG 1965 \\
\hline Canis familiaris & $11 \mathrm{dni}$ & DOAK i współaut. 1967 \\
\hline \multicolumn{3}{|c|}{ kopytne } \\
\hline Equus caballus & 6 dni & DAY 1942 \\
\hline Sus scrofa & 2 dni & ENSMINGER 1970 \\
\hline Camelus bactrianus & 2 dni & CHENG i YuAN 1984 \\
\hline Bos taurus & 2 dni & VANDEPLASSCHE i PAREDIS 1948 \\
\hline Ouis aries & 2 dni & BISHOP 1961 \\
\hline \multicolumn{3}{|c|}{ naczelne } \\
\hline Homo sapiens & do 5 dni & np. Wilcox i współaut. 1995 \\
\hline
\end{tabular}

odwzorowania charakteru biochemicznego i fizjologicznego naturalnego środowiska (dróg rodnych samic), w którym przechowywane plemniki zachowują zdolność do zapłodnienia. Trudnościa jest także tempo rozmrażania nasienia. U ryb proces zamrożenia i odmrożenia plemników dodatkowo skraca i tak krótki czas ich ruchliwości, należy więc użyć nasienia do zapłodnienia bardzo szybko od chwili rozmrożenia. Kolejnym utrudnieniem jest fakt niewielkiej przeżywalności plemników (15-40\%), co wiąże się $z$ koniecznościa użycia większej ilości nasienia niż w przypadku naturalnego zapłodnienia (GLOGOWSKI i współaut. 2007).

Mimo opisanych trudności w stosowaniu kriokonserwowanego nasienia, krioprezerwacja ma także wiele zalet. Sa to m.in.: bezpieczna i mało kosztowna wymiana materiału między ośrodkami badawczymi (kriokonserwowane plemniki zamiast żywych samców), przechowywanie genomów cennych linii hodowlanych, możliwość tworzenia mieszańców międzygatunkowych, których okresy rozrodcze sa od siebie znacznie oddalone w czasie, oraz wiele innych. To wszystko spra- wia, że wciąż próbuje się opracować nowe, coraz lepsze techniki skutecznej krioprezerwacji nasienia.

Badania ostatnich lat zwiazane $z$ proteomika (badania dotyczące białek) nasienia ryb (CIERESZKO i współaut. 2017) umożliwiły lepsze zrozumienie mechanizmów działających podczas kriokonserwacji plemników. Wpłynęło to na zwiększenie sukcesu zapłodnienia ryb tak przechowywanym nasieniem.

W hodowli bydła i trzody chlewnej naturalne krycie zostało zastapione przez sztuczne unasiennianie, co pozytywnie wpłynęło na populacje zwierzat gospodarskich. Obecnie jest to procedura stosowana powszechnie, głównie ze względu na niskie koszty i wysoką skuteczność w hodowli. Jednak według najnowszych badań przeprowadzonych na nasieniu pobranym od knurów (BIELAS i współaut. 2017), podatność struktury DNA plemników na uszkodzenia wzrasta wraz $z$ długością czasu przechowywania nasienia. Jedynie podczas pierwszych 7 dni od pobrania plemniki pozostaja prawie niezmienione, dlatego w niektórych przypadkach sztuczna inseminacja zastępowana jest transferem 
zarodków. U zwierzat domowych, w przeciwieństwie do mięsożernych czy naczelnych, implantacja zarodków nie jest procesem inwazyjnym (ZIĘCIK i współaut. 2007).

Obecnie badana jest nowa metoda, która może stać się alternatywa dla kriokonserwacji nasienia. Liofilizacja plemników umożliwia przechowywanie ich w temperaturze otoczenia lub w lodówce, zamiast w ciekłym azocie, który stosuje się do krioprezerwacji. Metoda ta znacznie ułatwiłaby magazynowanie nasienia, jednak wciąz trwaja badania nad zapewnieniem plemnikom ochrony przed uszkodzeniem DNA podczas procesu liofilizacji (OlACIREGUI i GIL 2017).

\section{PODSUMOWANIE}

Występowanie wśród zwierząt inseminacji sprzyjało wykształceniu struktur służących magazynowaniu plemników zdolnych do zapłodnienia. Dotychczasowy stan wiedzy na temat mechanizmów tego zjawiska wpłyną na rozwój technik umożliwiajacych pobranie i krioprezerwację nasienia oraz możliwość zapłodnienia w warunkach laboratoryjnych. Zagadnienie to jest obecnie wciaż intensywnie badane, dlatego powiększajacy się stan wiedzy pozwala na udoskonalanie praktycznie stosowanych metod sztucznej inseminacji.

\section{Streszczenie}

Pojawienie się inseminacji w ewolucji kręgowców pozytywnie wpłynęło na sukces rozrodczy zwierząt, gdyż zwiększyło prawdopodobieństwo fuzji gamet męskich i żeńskich, a tym samym możliwość zapłodnienia. Przetrzymywanie plemników w układzie rozrodczym samic umożliwiło wydłużenie ich żywotności i zdolności do zapłodnienia plemników poprzez zapewnienie im odpowiednich warunków otaczającego środowiska. W tym celu u samic wielu gatunków kręgowców zostały wykształcone struktury wyspecjalizowane do przechowywania plemników. Okres magazynowania plemników jest bardzo zróżnicowany wśród kręgowców, ale znacznie dłużej sa one przechowywane u gatunków zmiennocieplnych niż stałocieplnych.

\section{LITERATURA}

ADAMS C. S., COOPER W. E., 1988. Oviductal morphology and sperm storage in the keeled earless lizard Holbrookia propinqua. Herpetologica 44, 190-197.

ALLEN W. B., 1955. Some notes on reptiles. Herpetologica $11,228$.

AMOROSO E. C., 1960. Viviparity in fishes. Symp Zool Soc London I, 153-181. www.amphibiaweb.org

Astheimer L. B., Prince P. A., Grau G. R., 1985. Egg formation and the pre-laying period of Black-browed and Grey-headed Albatrosses Diomedea melanophris and D. chrysostoma at Bird Island, South Georgia. Ibis 127, 523-529.
ATSATT R., 1953. Storage of sperm in the female chameleon Microsaura pumila pumila. Copeia, 59.

BARNEY R. L., 1922. Further notes on the natural history and artificial propagation of the diamond-back terrapin. Fish. Bull. (Wash. D. C.) 38, 91-111.

BedFORD J. M., Mock O. B., NAGdas S. K., WinFREY V. P., OLSON G. E., 1999. Reproductive features of the eastern mole (Scalopus aquaticus) and star-nose mole (Condylura cristata). J Reprod. Fertil. 117, 345-53.

BiElaS W., NiŻAńsKi W., PARTYKA A., RZÅSA A., MORDAK R., 2017. Effect of long-term storage in Safe Cell+ extender on boar sperm DNA integrity and other key sperm parameters. Acta Vet. Scand. 59, 58.

BIRD D. M., BUCKLAND R., 1976. The onset and duration of fertility in the American kestrel. Can. J. Zool. 54, 1595-1597.

BIRKHEAD T. R., 1987. Prolonged sperm storage in domesticated canaries. Auk 104, 770-771.

BIRKHEAD T. R., 1988. Behavioral aspects of sperm competition in birds. Adv. Stud. Behav. 18, 35-72.

BiRKHEAD T. R., Møller A. P., 1992. Numbers and size of sperm storage tubules and the duration of sperm storage in birds: a comparative study. Biol. J. Linn. Soc. 45, 363-372.

BirkHEAD T. R., Møller A. P., 1993. Sexual selection and the temporal separation of reproductive events: sperm storage data from reptiles, birds and mammals. Biol. J. Linn. Soc. 50, 295-311.

Bishop D. W., 1961. Biology of spermatozoa. [W:] Sex and internal secretions. Young W. C. (red.). Tindall and Cox, Baillitre, London, 707-796.

Bou-Resli M. N., Bishay N. L. F., Al-Zaid N. S., 1981. Observations on the fine structure of the sperm storage crypts in the lizard Acanthodaclylus scutellatus hardyi. Arch. Biol. 92, 287-298.

Boyd U., Boyd N. S., Dobler F. C., 1977. Reproduction in prairie falcons by artificial insemination. J. Wildl. Manage. 41, 266-271.

BURNS J. R., WEITZMAN S. H., 2005. Insemination in ostariophysan fishes. [W:] Viviparous fishes. GRIER H. J., URIBE M. C. (red.). New Life Publications, Homestead, Florida, 107-134.

BurNS J. R., WeitzMAN S. H., MALABARBA L. R., 1997. Insemination in Eight Species of Cheirodontine Fishes (Teleostei: Characidae: Cheirodontinae). Copeia, 433-438.

Calsbeek R., Manoukis N., Bonneaud C., SMith T. B., 2007. Multiple paternity and sperm storage lead to increased genetic diversity in Anolis lizards. Evol. Ecol. Res. 9, 495-503.

CARSON H. L., 1945. Delayed fertilization in a captive indigo snake with notes on feeding and shedding. Copeia, 222-225.

CHANG M. C., 1965. Fertilizing life of ferret sperm in the female tract. J. Exp. Zool. 158, 87-99.

CHENG B. X., YUAN Z. X., 1984. Reproductive pattern of the Bactrian camel. [W:] The camelid: an all-purpose animal. COCKRILL W. R. (red.). Uppsala: Institute of African Studies, 364386.

Christensen V. L., Bagley L. G., 1989. Efficacy of fertilization in artificially inseminated turkey hens. Poult. Sci. 68, 724-729.

CIERESZKO A., DiETRICH M. A., NyNCA J., 2017. Fish semen proteomics - New opportunities in fish reproductive research. Aquaculture 472, 81-92. 
CONSTANTZ G. D., 1984. Sperm competition in Poeciliid fishes. [W:] Sperm competition and the Evolution of Animal Mating Systems. SMITH R. L. (red.). Academic Orlando Press, 465-485.

Cuellar O., 1966. Dealyed fertilization in the lizard Uta stansburiana. Copeia, 549-552.

DAREVSKY I. S., 1971. Delayed fertilization in the Brazilian colubrid snake Xenodon merremil (Wagler). J. Herpet. 5, 82-83.

Darling J. D. S., Noble M. L., Shaw E., 1980. Reproductive strategies in the surfperches. 1 . Multiple insemination in natural-populations of the shiner perch, Cymatogaster aggregata. Evolution 34, 271-277.

DAVENPORT M., 1995. Evidence of possible sperm storage in the caiman, Paleosuchus palpebrosus. Herp. Rev. 26, 14-15.

DAY F. T., 1942. Survival of spermatozoa in the genital tract of the mare. J. Agr. Sci. 32, 108111.

DoAK R. L., Hall A., Dale H. E., 1967. Longevity of spermatozoa in the reproductive tract of the bitch. J. Reprod. Fert. 13, 51-58.

EWING H. E., 1943. Continued fertility in female box turtles following mating. Copeia, 112-114.

ELDER W. H., WELleR M. W., 1954. Duration of fertility in the domestic mallard hen after isolation from the drake. J. Wildl. Manage. 18, 495-502.

ElofSSON H., VAN LOOK K. J., Sundell K., SundH H., BORG B., 2006. Stickleback sperm saved by salt in ovarian fluid. J. Exp. Biol. 209, 4230-4237.

ENSMINGER M. E., 1970. Swine science. Interstate Printers, Danville, Illinois. www.fishbase.org

FUKADA H., 1986. Delayed fertilization in the Japanese mamushi. Jpn J Herpet 11, 156-157.

GABE M., SAINT-GIRONS H., 1965. Histologie de Sphenodon punctatus. Centre National de la Rerherrhes Scientifique, Paris.

GARDINER D. M., 1978. Fine structure of the spermatozoon of the viviparous teleost, Cymatogaster aggregata. J. Fish Biol. 13, 435-438.

GEE G. F., 1983. Avian artificial insemination and semen preservation. [W:] On breeding birds in captivig. DELACOUR J. (red.). IFCB Symposium, North Hollywood, California, 375-398.

GlogowsKI J., KowAlSKI R., CIERESZKO A., 2007. Biologia i kriokonserwacja nasienia ryb. [W:] Biologia rozrodu zwierzat. T2 Biologiczne uwarunkowania wartości rozwodowej samca. STRZEŻEK J. (red.). Wydawnictwo uniwersytetu Warmińsko-Mazurskiego w Olsztynie, Olsztyn, 265-294

GLOYD H. K., 1928. The amphibians and reptiles of Franklin Co. Kansas. Trans. Kans. Acad. Sci. 31, 115 .

GODFREY G. K., 1969. Reproduction in a laboratory colony of the marsupial mouse Sminthopsis macroura (Marsupilia: Dasyuridae). Aust. J. Zool. 17, 637-654.

GRIER J. W., 1973. Techniques and results of artificial insemination with golden eagles. J. Raptor Res. 7, 1-12.

GRIER H. J., 1981. Cellular organization of the testis and spermatogenesis in fishes. Am. Zool. 12, 345-357.

GROVES J. D., 1973. Delayed fertilization in the snake Boiga dendrophila. Herpetologica 29, 20-21.

GuilletTe L. J., Sullivan W. P. JR., 1985. Reproductive and fat body cycles of the lizard. Sceloporus formosus. J. Herpet. 19, 474-480.

HAINES T. P., 1940. Delayed fertilization in Leptodeira annulata polysticta. Copeia, 116-118.
HAMMOND J., ASDELL S. A., 1926. The vitality of the spermatozoa in the male and female rabbit. J. Exp. Biol. 4, 155-185.

HATTAN L. R., Gist D. H., 1975. Seminal Receptacles in the Eastern Box Turtle, Terrapene carolina. Copeia, 3, 505-510.

HENLEY C., 1975. An occurrence of amphigonia retarda in the white-lipped viper Trimeresum albolabris. Herpetol. Rev. 6, 42.

Hill J. P., O'Donoghue U. I., 1913. The reproductive cycle in the marsupial Dasyurus viverrinus. Q. J. Microsc. Sci. 59, 133-1 74

HIRAIWA Y. K., UCHIDA T., 1956. Fertilization capacity of spermatozoa stored in the uterus after copulation in the fall. Sci. B Fac. Agr. Kyushu 31, 565-574.

HOAR W. S., 1969. Reproduction. [W]: Fish Physiology. Vol III. Reproduction and Growth, Bioluminescence, Pigments and Poisons. HOAR W. S., RANDAL J. J. (red.). Academic Press, New York, 1-72.

HOGART P. J., 1976. Viviparity. Studies in Biology. Arnold, London.

HUNTER R. H. F., 1984. Pre-ovulatory arrest and periovulatory redistribution of competent spermatozoa in the isthmus of the pig oviduct. J. Reprod. Feri. 72, 203-211.

JAVONILLO R., BURNS J. R., WeitzMAN S. H., 2009. Sperm modifications related to insemination, with examples from Ostariophysi. [W]: The reproductive biology and phylogeny in fishes. JAMIESON B. G. M. (red.). Science Publishers, Enfield (NH), 723-763.

JoHNSON A. S., 1954. Artificial insemination and the duration of fertility in geese. Poult Sci 33, 638-640.

JUN-YI L., 1982. Sperm retention in the lizard Chameleo hoehnelii. Copeia, 488-489.

KLUTH F., 1936. Ungewöhnlich spate Eiablage bei Schlangen. Bl Aquar und Terrak 47, 20.

KOPEIKA E., KOPEIKA J., 2008. Variability of sperm quality after cryopreservation in fish. [W]: Fish spermatology. ALAVI S. M. H., COSSON J., COWARD K., RAFIEE G. (red.). Alfa Science Int. Ltd, Oxford, UK, 347-396.

KOPSTEIN F., 1938. Ein beitrag zur eierkunde und zur fortpflanzung der malaiischen reptilian. Bull Raffles Mus 14, 81-167.

Koya Y., MunehaRA H., TAKANO K., 2002. Sperm storage and motility in the ovary of the marine sculpin Alcichthys alcilcornis (Teleostei: Scorpaeniformes), with internal gametic association. J. Exp. Zool. 292, 145-155.

KuehNel S., KuPfer A., 2012. Sperm storage in caecilian amphibians. Front. Zool. 9, 12.

LAHNSTEINER F., PATZNER R. A., 2007. Sperm morphology and ultrastructure in fish. [W]: Fish spermatology. ALAVI S. M. H., COSSON J., COWARD K., RAFIEE G. (red.). Alfa Science Int. Ltd, Oxford, 1-62.

LEPTEIN R., 1989. Zur haltung eines weibchens von Chameleo ellioti (Gunther, 1895) mit dem nachweis von amphigonia retarda. Salamandra 25, 21-24.

LichT P., 1973. Influence of temperature and photoperiod on the annual ovarian cycle in the lizard, Anolis carolinnuis. Copeia, 465-472.

LUDWIG M., RAHN H., 1943. Sperm storage and copulatory adjustment in the prairie rattlesnake. Copeia, 15-18.

MANGUSSON W. E., 1979. Production of an embryo by Acrochordas vavanicus isolated for seven years. Copeia, 744-745.

MEISNER A. D., 2005. Male modifications associated with insemination in teleosts. [W]: Viviparous fishes. Grier H. J., Uribe M. C. (red.). 
New Life Publications, Homestead, Florida, 165-190.

METTER D. E., 1964. On breeding and sperm retention in Ascaphus. Copeia, 710-711.

Moore J. A., NELSON N. J., KeAll S. N., DAUGHERTY CH. H., 2008. Implications of social dom inance and multiple paternity for the genetic diversity of a captive-bred reptile population (tuatara). Conserv. Genet. 9, 1243-1251.

Munehara H., OKAMOTO H., ShimazaKi K., 1990. Paternity estimated by isozyme variation in the marine sculpinAlcichthys alcicornis (Pisces: Cottidae) exhibiting copulation and paternal care. J. Ethol. 8, 21-24.

NALBANDOV A., CARD L. E., 1943. Effect of stale sperm on fertility and hatchability of chicken eggs. Poult. Sci. 22, 218-226.

NiCKERSON M., 1974. Comments on the reproduction of Pope's pit-viper (Trimeresurus popeorum) Smith. Brit. J. Herpet. 5, 451-452.

NiELSEN J. G., 1984. Two new, abyssal barathronus sp. from the North Atlantic (Pisces: Aphyonidae). Copeia, 579-584.

NoBle G. K., 1925. An outline of the relation of ontogeny to phylogeny within the Amphibia I. Am. Mus. Novit. 165, 1-17.

OlaciREgUi M., GIL L., 2017. Freeze- dried spermatozoa: A future tool? Reprod. Dom. Anim. $52,248-254$

OWEN R. D., 1941. Artificial insemination of pigeons and doves. Poult. Sci. 20, 428-431.

Palmer B. D., GuilletTe L. C., 1988. Histology and functional morphology of the female reproductive tract of the tortoise Gopherus polyphemus. Am. J. Anat. 183, 200-211.

Palmer K. S., Rostal D. C., GRUMBles J. S., Mulvey M., 1998. Long-term sperm storage in the desert tortoise (Gopherus agassizii). Copeia, $702-705$.

PARKER G. A., 1970. Sperm competition and its evolutionary consequences in the insects. Biol. Rev. 45, 525-567.

PARKER H., 1989. Duration of fertility in capercaillie hens after separation from the mate. Ornis. Scand. 20, 307-310.

Pearse D. E., JANZen F. J., AVISE J., C., 2001. Genetic markers substantiate long-term storage and utilization of sperm by female painted turtles. Heredity 86, 378-384.

PECIO A., 2001. Ewolucja żyworodności wśród ryb. Przegl. Zool. 3-4, 239-252.

PECIO A., 2003. Spermiogenesis and fine structure of the spermatozoon in a headstander, Chilodus punctatus (Teleostei, Characiformes, Anostomidae). Folia Biol. 51, 55-62.

PECIO A., 2010. Morfologiczne modyfikacje zwiazane $z$ inseminacja $w$ układzie rozrodczym samców ryb kasaczowatych $z$ podrodzin Glandulocaudinae $i$ Stevardiinae (Teleostei: Characiformes: Characidae). Wydawnictwo Uniwersytetu Jagiellońskiego, Kraków.

PECIO A., 2012. O ewolucji żyworodności wśród kręgowców. Wszechświat 4-6, 106-112.

PECIO A., RAFIŃSKI J., 1985. Sexual behaviour of the Montandon's newt, Triturus montandoni (Boulenger)(Caudata: Salamandridae). Amphibia-Reptilia 6, 11-22.

PetiTJEAN M. J., 1966. De quclques applications pratiques de I'insemination artificelle en aviculture. Rev. Elev. 21, 109-117.

PhILIPP G. A., 1979. Sperm storage in Moloch horridus. West Aust. Nat. 14, 161.

POTTER H., KRAMER C. R., 2000. Ultrastructural observations on sperm storage in the ovary of the platyfish, Xiphophorus maculates (Tele- ostei: Poeciliidae): the role of the duct epithelium. J. Morphol. 245, 110-129.

PRATT H. L. J., 1993. The storage of spermatozoa in the oviducal glands of western north Atlantic sharks. Environ. Biol. Fish. 38, 139-149.

PUSEY B. J., STEWART T., 1989. Internal fertilization in Lepidogalaxias salamandroides Mees (Pisces: Lepidogalaxidae). Zool. J. Linn. Soc. 97, 69-79.

RACEY P. A., 1982. Ecology of bat reproduction. [W:] Ecology of bats. KUnZ T. (red.). Plenum, London, 57-104.

RAFIŃSKI J., OSIKOWSKI A., 2002. Sperm mixing in the Alpine newt (Triturus alpestris). Canad. J. Zool. 80, 1293-1298.

RAHN H., 1940. Sperm viability in the uterus of the garter snake, Thamnophis. Copeia, 109115.

RISLEY P. L., 1933. Observations on the natural history of the common musk turtle Sternotherus odorutus (Latreille). Pap. Mich. Acad. Sci. Arts. Lett. 17, 685-711.

RODGER J. C., BEDFORD J. M., 1982. Induction ofoestrus, recovery of gametes and the timing of fertilization events in the opposum Didelphis uirginiana. J. Reprod. Fert. 64, 159-169.

RollinAT R., 1946. La uie des reptiles de la France centrale. Libraire Delagrave, Paris.

RożNIATOWski T., 1981. Polski Słownik Medyczny. Państwowy Zakład Wydawnictw Lekarskich, Warszawa, 437.

SAINT-GIRONS H., 1982. Reproductive cycles of male snakes and their relationship with climate and female reproductive cycles. Herpetologica 38, 5-16.

SchaEFfer G. C., Roeding C. E., 1973. Evidence for vaginal sperm storage in the mole skink Eumeces egregius. Copeia, 346-347.

SCHICK C., 1947. Sex ratio-egg fertility relationships in the ring-necked pheasant. J. Wildl. Manage. 11, 302-306

SCHUETT G. W., 1992. Is long-term sperm storage an important component of the reproductive biology of temperate pitvipers? [W:] Biology of Pitvipers. CAMPBEll J. A., BRODIE E. D. (red.). SELVA, Texas, 169-184.

SCHULTZ E. T., 2008. A sex difference in seasonal timing of birth in a livebearing fish. Copeia, 673-679.

SELWOOD L., 1987. Relationship between longevity of spermatozoa after insemination and the percentage of normal embryos in brown marsupial mice (Antechinus stuartii). J. Reprod. Fert. 79, 495-503.

SEVER D. M., 2002. Female Sperm Storage in Amphibians. J. Exp. Zool. 292, 165-179.

Sever D. M., Moriarty E. C., Rania L. C., HamLETT W. C., 2001. Sperm storage in the oviduct of the internal fertilizing frog Ascaphus truei. J. Morphol. 248, 1-21.

SмYTH M. Y., SMITH M. J., 1968. Obligatory sperm storage in the skink Hemiergis peronii. Science, Washington 161, 575-576.

Soderwall A. L, Young W. C., 1940. The effect of ageing in the female genital tract of the fertilizing capacity of guinea pig spermatozoa. Anat. Rec. 78, 19-29.

Soderwall A. L., Blandou R. J., 1941. The duration of the fertilizing capacity of spermatozoa in the genital tract of the rat. J. Exp. Zool. 88, 55-63.

SPILlER N. I., GRAHAME I., Wise D. R., 1977. Experiments on the artificial insemination of pheasants. J. World Pheas. Assoc. 2, 89-96. 
STAVY M., TERKEL J., 1992. Interbirth interval and duration of pregnancy in hares. J. Reprod. Fert. 95, 609-615.

STEWART G. R., 1972. An unusual record of sperm storage in a female garter snake (genus Thamnophis). Herpetologica 28, 346-347.

Stille B., Madsen T., NikLASsON M., 1986. Multiple paternity in the adder Vipera berus. Oikos $47,173-175$.

STORRIE M. T., WALKeR T. I., LAURENSON L. J., HAMLETT W. C., 2008. Microscopic organization of the sperm storage tubules in the oviducal gland of the female gummy shark (Mustelus antarcticus), with observations on sperm distribution and storage. J. Morphol. 269, 1308-1324.

SUAREZ S. S., 1987. Sperm transport and motility in the mouse oviduct: observations in situ. Biol. Reprod. 36, 203-10.

Thibault C., Levasseur M. C., 1973. Conservation et survive prolongee des spermatozoides dans les vois genitales femelles des vertebres. Ann. Biol. Anim. Biochim. Biophys. 13, $767-$ 784.

TRAPIDO H., 1940. Mating time and sperm viability in Storeria. Copeia, 107-109.

Tyndale-Biscoe C. H., RodGer J. C., 1978. Differential transport of spermatozoa into the two sides of the genital tract of a monovular marsupial, the tammar wallaby (Macropu eugenii). J. Reprod. Fertil. 52, 37-43.

Ullmnan S. L., 1976. Anomalous litters in hybrid mice and the retention of spermatozoa in the female tract. J. Reprod. Fertil. 47, 13-18.

UlRICH C. F., PARKes A. S., 1978. The green sea turle (Chelonia mydas): further observations on breeding in captivity. J. Zool. 185, 237-251.
VANDEPLASSCHE M., PAREDIS R., 1948. Preservation of the fertilizing capacity of bull semen in the genital tract of the cow. Nature 162, 813.

Vila S., Sabat M., HeRnandez M. R., MunOZ M., 2007. Intraovarian sperm storage in Helicolenus dactylopterus dactylopterus: fertilization, crypt formation and maintenance of stored sperm. Raffles B Zool. 14 (Suppl.), 21-27.

WERNER D. I., 1982. Social organization and ecology of land iguanas Conolophus subcristatus, on Isla Fernandina, Galapagos. [W:] Iguanas of the world: their behavior, ecologv and conservation. BURGHARDT G. M., RAND S. A. (red.). Noyes, New Jersey, 342-365.

WILCOX A. J., WEINBERG C. R., BAIRD D. D., 1995. Timing of sexual intercourse in relation to ovulation. Effects on the probability of conception, survival of the pregnancy, and sex of the baby. N. Engl. J. Med. 333, 1517-1521.

WIMSATT W. A., 1944. Further studies on the survival of spermatozoa in the female reproductive tract of the bat. Anat. Rec. 88, 193-204.

WOODWARD S. F., 1933. A few notes on the persistence of active spermatozoa in the African night aduder, Causus rhombeatus. Proc. Zool. Soc. Lond. 103, 189-190.

WOURMS J. P., 1981. Viviparity: the maternal-fetal relationship in fishes. Am. Zool. 21, 473-515.

ZIECIK A., KACZMAREK M., BOGACKI M., 2007. Oogeneza, zapłodnienie, implantacja zarodka $i$ okres wczesnej ciaży. [W:] Fizjologiczna regulacja procesów rozrodczych samicy. KRZYMOWSKI T. (red.). Wydawnictwo Uniwersytetu Warmińsko-Mazurskiego w Olsztynie, Olsztyn, 331-364.

KOSMOS Vol. 67, 4, 841-853, 2018

AnNa DymeK, ANNA PECIO

Department of Comparative Anatomy, Institute of Zoology and Biomedical Research, Faculty of Biology, Jagiellonian University, 9 Gronostajowa Str., 30-387 Kraków, E-mail: anna.tyrkalska@doctoral.uj.edu.pl

\section{VICISSITUDES OF SPERM AFTER INSEMINATION.VARIOUS ASPECTS OF FEMALES SPERM STORAGE IN THE WILD AND IN LABORATORY CONDITIONS}

\section{Summary}

Insemination significantly increases the success of reproduction. Many species evolved special structures for sperm storage in female reproductive tracts, which ensure suitable conditions for the sperm. This allows for prolonged life of sperm without loss of fertilization ability. Duration of sperm storage depends on the species and varies from few hours to several years. 